\title{
The Impact of Metadiscoursal Features on Online Reading Ability of EFL Learners
}

\author{
Ali Zahabi \\ School of languages, Literacies and translation, University Sains Malaysia, Penang, Malaysia \\ Email: ali-zahabi@hotmail.com \\ Hamed Ghaemi \\ English Department, Islamic Azad University (IAU), Gonabad Branch, Gonabad, Iran \\ Email: hamedghaemi@ymail.com \\ Ambigapathy Pandian \\ School of Languages, literacies and translation, University Sains Malaysia, Penang, Malaysia \\ Email: ambiga@usm.my
}

\begin{abstract}
The internet has become essential in the education of learners of all ages across the world but it has become particularly significant in the reading development of EFL learners. The present study aims at investigating the role and importance of metadiscourses in online reading comprehension of EFL learners. To meet this purpose, a questionnaire of Metadiscourses was developed and given to all subjects. Also, all participants were required to take part in an online reading comprehension test named as DIALANG Diagnostic Language Testing Online. The findings of the study illustrated that about $75 \%$ of the variation in online reading ability can be explained by taking their level of metadiscourse awareness into account. Therefore; metadiscourse awareness is making a significant contribution to the prediction of online reading ability.
\end{abstract}

Index Terms — online reading test, metadiscourse, DIALANG Diagnostic Language Testing Online

\section{BACKGROUND TO THE STUDY}

\section{A. Complex Facets of Online Reading Comprehension}

The Internet provides an abundance of potential benefits for learners with disabilities; however, certain characteristics of online reading comprehension present learners with greater challenges and further complexity than reading printed text. Unlimited amounts of information online are more complex for learners to locate relevant information (Abbott \& Cribb (2001), Leu, Kinzer, Coiro \& Cammack (2004), McKenzie (1995), and Pierce (1998). The main advantages of online reading activities are the following:

Access at any time, in any place, for unlimited number of times, for unlimited time, without any charge and grate abundance of topics to choose from, so every student may find something interesting, next, the other advantage is that most sites are fully interactive, in that they check students' answers, give correct ones and provide feedback on incorrect ones, due to these factors, students are able to develop their reading skills without the teacher, providing they have the access to the Internet. The online learning environment has become more and more popular for educators and learners, due to its multiple visual and audio representations. Reading online is further complicated by the need to critically evaluate online sources to determine the reliability of the information (Abbott \& Cribb (2001), Bulger (2006), Leu, Kinzer, Coiro \& Cammack (2004). online texts and reading contexts change rapidly, often from one day to the next. Designers update their websites and readers post new comments using social networking tools. This rapidly changing reading environment has implications for the reliability of assessments that measure online reading comprehension; however, online materials must be evaluated for reliability, which learners generally neglect, and make it as a controversial issue; therefore evaluation strategies must be taught (Pierce, 1998). In addition to the complexities of this issue that is both relevant and reliable, multimedia components imbedded in online reading adds to the complex nature of Internet reading because unique skills for processing multiple modes of information is required because it includes embedded links, graphics, and video that sometimes distract learners, causing a decrease in comprehension rather than the intended enhancement of comprehension and retention (Coiro(2005), Kennedy \& Bolitho(1984), Leu, Kinzer, Coiro \& Cammack (2004). Although barriers are present preventing progress towards improved online literacy for learners with disabilities, when efforts for integration are made, learners obtain considerable benefit from learning online reading comprehension skills and strategies.

\section{B. Benefits of Integrating the Internet into Instruction}


Although research is scarce, a body of literature identifies the advantageous nature of the Internet for improving the academic outcomes for learners with disabilities including: (a) unlimited access to various resources, (b) adaptability, (c) increased opportunities for communication, and (d) the motivational aspect. One such benefit of the Internet is the access at any time, in any place, for unlimited number of times, without any charge. Another noteworthy aspect of the Internet is the ease of adapting online materials for learners with disabilities, and availability of a large number of topics for students to choose, particularly for those learners with exceptionalities being educated in inclusive settings. Furthermore the website is fully interactive and can be used by students, thus improving positive social and interpersonal skills that learners with disabilities often lack (Burgstahler, (1997), Hutinger, Clark \& Johnson (2001). A final and ubiquitous theme is found within relevant literature describing the motivational nature of Internet. Motivation has to come from within an individual and from external support. Incentive can be lost when people believe they have no control or choice, no skills or resources to be successful, and no external resources to turn to for help. A key to successfully motivating an online student is to meet individual needs in terms of control, competence and belonging. Due to the tremendous potential for improving academic and social outcomes for learners with disabilities and the barriers preventing more widespread and meaningful implementation of the Internet into instruction, a dire need to increase research and practice efforts of online reading comprehension exists. While small, the body of research in the area indicates that teaching online reading comprehension is generally a promising practice to enhance learning for learners with disabilities. However, barriers to implementing this promising practice, along with the unique nature of online reading, hinders both instruction and student achievement.

Recent trends in the study of written texts reflect a growing interest in interaction between readers and writers. Several studies have focused on metadiscourse as an important interactive feature that is believed to facilitate the reading process. With reference to Halliday (1985b), metafunctional theory of language, on the interpersonal level, (Schiffrin (1980), Hyland (2000), Crismore \& Farnsworth (1990), both point out that metadiscourse allows written texts to take on some features of spoken language (e.g., personal pronouns to establish an "I-you" relationship), and thus become more "reader-friendly". On the textual level, (Crismore \& Farnsworth (1990), Crismore (1989) note that Metadiscourse is a term that is used in philosophy to denote a discussion about a discussion (and so on), as opposed to a simple discussion about a given topic. The term metadiscourse is also used in writing to describe a word or phrase that comments on what is in the sentence, usually as an introductory adverbial clause. It is any phrase that is included within a clause or sentence that goes beyond the subject itself, often to examine the purpose of the sentence or a response from the author.

Metadiscourse occurs within the realm of writing, whose presence we may verify by words, sentences, and paragraphs. Definitions and classifications of metadiscourse have been proposed by (Williams \& Joseph (1990), Crismore \& Farnsworth (1990), Crismore \& Vande Kopple (1997) and Hutchinson \& Waters (1987) who explains its usefulness during the writing process toward helping readers interpret and understand textual content. Metadiscourse helps writers arrange content by providing cues and indicators that both help readers proceed through texts and influence its reader reception.

Expanding metadiscourse to the visual realm both alters and confirms the concept of metadiscourse as defined for text. An alteration of metadiscourse occurs in the distinction of metadiscourse words from the content on which they are applied. In the definition by Williams that metadiscourse is "writing about writing," we see a separation between the writing on one level and the other writing at a different level we call metadiscourse. Writing at the first level (Vande Kopple (1997) calls the propositional content and it may be affected by metadiscourse from any of his seven categories.

In a later study with ninth graders, (Crismore (1989) \& Vande Kopple (1997) investigated the effects of hedging (e.g., metadiscursive devices that express the writer's commitment to the truth value of the proposition being made) on reading retention. Experimental groups read passages from both social studies and science textbooks containing various types of hedging, while a control group read corresponding passages in which all hedging had been removed. Even if other factors (e.g. gender, subject matter and type/position of hedging) were also found to have an influence on retention scores, the authors propose that, in general, learners learned more from reading science and social studies passages with hedging included. Hedging is a strategy in which you state conditions, qualifications, exceptions to an assertion you are making. Hedging is an admission that something out there might contradict your assertion; it is an upfront admission of doubt in your own assertion.

\section{WHAT IS METADISCOURSE?}

Metadiscourse is talk about talk. The common term discourse refers to the pragmatic use of language (including nonverbal signs such as paralanguage and gestures in discourse) in extended texts or episodes of communication. Metadiscourse refers to the pragmatic use of language to comment reflexively on discourse itself. The prefix "meta" (from a Greek word meaning with, across, or after) here denotes a shift to a higher-order frame of reference. Metadiscourse shifts the focus of attention from ongoing communication, putting some stretch of discourse in a context or frame designed to influence the meaning and practical conduct of communication.

Williams (1990), gives a different definition of metadiscourse from the one developed by (Hyland, (2000), \& Hyland, Ken (2005). It is — the language we use when, in writing about some subject matter, we incidentally refer to the act and to the context of writing about it. He goes on give examples: verbs to announce what the writer will be doing; cohesion 
markers to indicate steps in presentation; words to express logical connections; and words to hedge how certain the writer is about a claim. Williams (1990) then states: - Though metadiscourse does not refer to what we are primarily saying about our subject, we need some metadiscourse in everything we write. $\|$ His wording (—incidentally, $\|$-not [...] to what we are primarily saying, $\|$-we need some metadiscourse $\|$ ) reflects a fundamental distinction that a number of theorists have made between propositional content (considered more important) and metadiscourse (considered less important).

In his critique of metadiscourse theory, Hyland (2005) reacts against the above dichotomy: — (...) language is not simply used to convey information about the world. It also acts to present this information through the organization of the text itself (...) and engage readers as to how they should understand it (...) $\|$ (Hyland (2005), \& Burgstahler (1997) sees these two communicative acts — presenting through organization of the text and engaging readers — as the core purpose of metadiscourse. Taking a largely functional, pragmatic and sociocognitive perspective, he opines that —all discourse, no matter how explicitly _informational, 'is created between participants who bring to the encounter certain affiliations, experiences, expectations and background understandings. These interpersonal dimensions influence how they will interpret and respond to the message and how they will engage in the interaction. This means, says (Hyland (2000), Hyland \& ken (2005) that writing involves managing social relationships - because a text communicates effectively only when the writer has correctly assessed both the reader's resources for interpreting it and their likely response to it. This is, in part, achieved through the use of metadiscourse. Here, Hyland's (2005) views echo Grice's Cooperative Principle and mesh with (Sperber, Dan, and Deidre Wilson (1995) \& Williams (1990)'s Relevance Theory, according to which the speaker or writer has a communicative and an informative intention. For the reader to interpret the writer's communicative and informative intentions correctly (i.e. in the way the writer wants them to), the writer must ensure, to the extent possible, that they share the same cognitive and contextual environment by using a variety of linguistic cues, including connectors. In a sense, it is through metadiscourse, as defined by Hyland, that the writer activates his/her communicative intention, which is more often than not to convince the reader of the information being conveyed and/or to persuade the reader to act on that information.

Thus Hyland (2005)'s own definition of metadiscourse revolves around the construction of text, meaning and the management of the writer-reader relationship:

All speech and writing, whether professional, academic or personal, includes expressions which refer to the text producer, the imagined receiver and the evolving text itself.... These expressions provide information about the participants, the kind of discourse that is being constructed, and the context. These expressions are, collectively, referred to as metadiscourse: aspects of a text which explicitly organize a discourse or the writer's stance towards either its content or the reader.

Metadiscourse is the cover term for the self-reflective expressions used to negotiate interactional meanings in a text, assisting the writer (or speaker) to express a viewpoint and engage with readers as members of a particular community (Sperber, Dan, and Deidre Wilson (1995) \& Hyland (2005).

In (Hyland (2005)'s opinion, the writer uses metadiscourse precisely to bring the implicit, internalized dialogue to a satisfactory conclusion through the reader's acceptance of the argument.

\section{A. Metadiscourse Typology}

Hyland divides metadiscourse into two broad categories:

- Interactive - features used to organize propositional information in ways that the target reader should find coherent and convincing (Halliday(1985a).

- Interactional - features that draw the reader into the discourse and give them an opportunity to contribute to it and respond to it by alerting them to the writer's perspective on propositional information and orientation and intention with respect to that reader (Halliday (1985a) \& Halliday (1985b).

\section{B. Interactive Metadiscourse}

There are five interactive features, which are briefly defined and exemplified below.

- Code glosses supply additional information by rephrasing, illustrating or explaining. They reflect the writer's assumptions about the reader's cognitive environment. Examples: called, defined as, e.g., in other words, specifically

- Endophoric markers refer to other parts of the text in order to make additional information available, provide supporting arguments, and thus steer the reader toward a preferred interpretation.

Examples: (in) (this) Chapter; see Section X, Figure X, page X; as noted earlier

- Evidentials are metalinguistic representations of an idea from another source and help to establish authorial command of the subject.

- Examples: (to) quote $X$, according to $X$

- Frame markers are used to sequence parts of the text or order arguments in the text. They serve four specific purposes:

(a) to sequence - (in) Chapter X, first, next, lastly, I begin with, I end with

(b) to label stages - all in all, at this point, in conclusion, on the whole

(c) to announce goals - my focus, goal, objective is to, I seek to

(d) to shift topic - back to, in regard to, return to, turn to 
- Transition markers are primarily conjunctions and conjunctives that help the readers determine the logical relationships between propositions. Authorities have proposed a number of categorizations, including (Hutchinson \& Waters(1987), Hyland (2005):

(a) Additive - moreover, for example (also an endophoric marker), similarly

(b) Causal - therefore, as a result, it follows that

(c) Adversative - however, that being said, nevertheless

(d) Temporal - first, second, next, then, finally

\section{Interactional Metadiscourse}

There are five interactional features too.

- Attitude markers indicate the writer's opinion or assessment of a proposition. Examples: I agree, I am amazed, appropriate, correctly, dramatic, hopefully, unfortunately

- Self-mention refers to explicit authorial presence in the text and gives information about his/her character and stance. Examples: I, we, the author

- Engagement markers explicitly address readers to draw them into the discourse. Examples: we, our (inclusive), imperative mood

- Hedges indicate the writer's decision to recognize other voices, viewpoints or possibilities and be (ostensibly) open to negotiation with the reader. Examples: apparently, assume, doubt, estimate, from my perspective, in most cases, in my opinion, probably, suggests

- Boosters allow the writer to anticipate and preclude alternative, conflicting arguments by expressing certainty instead of doubt. Examples: beyond doubt, clearly, definitely, we found, we proved, it is an established fact

\section{SignificAnCE OF THE StUdy}

Recent trends in the study of written texts reflect a growing interest in interaction between readers and writers. Several studies have focused on metadiscourse as an important interactive feature that is believed to smooth the progress of the reading comprehension. While several authors have studied metadiscourse from the descriptive and contrastive perspectives, there is a lack of experimental work on this topic.

The purpose of this research was to gain more insight into the influence of metadiscourse on online reading comprehension levels in an L2 setting: a group of Iranian EFL learners.

The following research question has been developed for the present study:

Q: Are L2 readers able to understand an online text containing more metadiscourse better than one with less?

\section{METHODOLOGY}

\section{A. Participants and Administration Procedures}

The test and questionnaire were administered to two large sections (ranging from 100-120 learners) of the EFL reading course. From those sections, two groups of 55 participants were randomly selected. Learners can enroll in the course starting only from the third year of their degree program. The English proficiency level of the learners ranged from intermediate to upper intermediate. The experiment was conducted towards the end of the semester-long course to prepare learners for an online reading comprehension test. The participants took an online reading comprehension test and completed a questionnaire. The online test is called DIALANG Diagnostic Language Testing Online.

\section{B. Instruments}

An online reading comprehension test was used in the current study. This test should be downloaded from the website of the Lancaster University and after installing the software, all the learners can use it provided that they are connected to the internet. This test is named as DIALANG Diagnostic Language Testing Online. The second instrument was the questionnaire of metadiscourse that measured the EFL learners' degree of awareness of metadiscourse. Unlike the online reading comprehension test, the questionnaire was formulated in Persian (the native language of the learners) in an attempt to avoid any failure to understand or correctly interpret the questions.

\section{DATa ANALYSIS AND DisCUSSION}

As mentioned earlier, the necessary data for the present study was collected through one Questionnaires of Metadiscourse filled by the EFL Learners and an online reading comprehension test.

The descriptive statistics of metadiscourse questionnaire as the independent (predictor) variable and online reading comprehension test as the dependent (predicted) variables are illustrated in the following Tables (see Table 1): 
TABLE 1.

DESCRIPTIVE STATISTICS FOR METADISCOURSE QUESTIONNAIRE AND READING COMPREHENSION TEST

\begin{tabular}{|l|l|l|l|l|l|}
\hline & $\mathrm{N}$ & Minimum & Maximum & Mean & Std. Deviation \\
\hline Metadiscourse Q & 55 & 11.00 & 20.00 & 15.0294 & 3.45549 \\
\hline Valid N (listwise) & 55 & & & & \\
\hline Online Reading & 55 & 11.00 & 38.00 & 27.6471 & 8.72900 \\
\hline
\end{tabular}

In order to describe the strength and direction of the linear relationship between the metadiscourse questionnaire and online reading test, Pearson Product Moment Correlation was applied to find the relationship between the two variables. The results of the correlation coefficients between metadiscourse questionnaire and online reading test are reported in Table.2.

TABLE 2.

PEARSON's CORRELATION MATRIX BETWEEN METADISCOURSE QUESTIONNAIRE \& ONLINE READING TEST

\begin{tabular}{llc}
\hline & Metadiscourse Questionnaire & Online Reading Test \\
\hline Metadiscourse Qquestionnaire & 1.00 & 1.00 \\
\hline Online Reading Test & $.76(* *)$ &
\end{tabular}

As the results in Table 2 indicate, there is a positive correlation between the two instruments $(r=.76, p<.05)$, showing a significant relationship between the level of metadiscourse awareness and Online reading ability.

Regression Analysis for Metadiscourse Questionnaire and Online reading test

To analyze the data further, regression analysis was conducted. The results indicated that Metadiscourse Questionnaire is a positive predictor of the dependent variable (Online reading test). The results of regression analysis for Metadiscourse Questionnaire and Online reading test are reported in Table 3.

As the results of Table 3 reveal, the model containing scores of Metadiscourse Questionnaire can predict $71 \%$ of the conceptual learning from the text. The $\mathrm{R}$ value is .84 indicating a correlation between students' metadiscourse awareness level and their online reading abilities.

TABLE 3.

R SQUARE FOR READING ENGAGEMENT AS THE PREDICTOR OF CONCEPTUAL LEARNING FROM TEXT

\begin{tabular}{lllll}
\hline Model & $\mathrm{R}$ & $\mathrm{R}$ Square & Adjusted R Square & Std. Error of the Estimate \\
\hline 1 & $.651(\mathrm{a})$ & .757 & .753 & 19.05734 \\
\hline Predictors: (Constant), Metadiscourse Questionnaire & & \\
\hline
\end{tabular}

Table 3 shows the contribution of the independent variable (Metadiscourse Questionnaire) on the dependent variable (Online reading) equals .651. The square value is .75 showing that about $75 \%$ of the variation in online reading ability can be explained by taking their level of metadiscourse awareness into account. Therefore; metadiscourse awareness is making a significant contribution to the prediction of online reading ability.

\section{CONCLUSION}

Today the reading situation of an adolescent has changed. While on the one hand the book exists as a conventional medium for the distribution and conception of knowledge, on the other hand, the web represents a new kind of reading room. Knowledge construction on the web needs the capability to lithely incorporate traditional reading comprehension skills with new strategic knowledge applications drawn out by the new reading field for processing, comprehending and sharing information. More accurately the web has become an essential source that extends the traditional reading comprehension picture into an open hypermedia and multimedia knowledge space where a set of online comprehension strategies are engaged to efficiently find, comprehend, and utilize the informational contents.

When learners are involved in Internet learning and communication activities, reading comprehension is influenced by the appearance of the contents to read: mail, blogs, social networks, multimedia and hypermedia contents introduce a primary alteration in the construction of acts of reading. In reality, reading comprehension becomes a more complex, ongoing, self regulated, decision process which involves selecting from different feasible links, possible texts, possible purposes and among different ways of interacting with information (Afflerbach \& Cho (2009).

The present study aims at investigating the role and importance of metadiscourses in online reading comprehension of EFL learners. To meet this purpose, a questionnaire of Metadiscourses was developed and given to all subjects. Also, all participants were required to take part in an online reading comprehension test named as DIALANG Diagnostic Language Testing Online. The findings of the study illustrated that about $75 \%$ of the variation in online reading ability can be explained by taking their level of metadiscourse awareness into account. Therefore; metadiscourse awareness is making a significant contribution to the prediction of online reading ability.

\section{REFERENCES}

[1] Abbott, C., \& Cribb, A. (2001). Special schools, inclusion, and the World Wide Web: The emerging research agenda [Electronic version]. British Journal of Educational Technology, 32, 331-342. 
[2] Leu. D.J., Jr., Kinzer, C.K., Coiro, J., \& Cammack, D. (2004). Towards a theory of new literacies emerging from the Internet and other ICT. In R.B. Ruddell \& N. Unrau (Eds.), Theoretical Models and Processes of Reading, 5th Edition, 1570- 1613.

[3] McKenzie, J. (1995). Direct connect: Beforenet and afternet. Multimedia Schools, 2(3), 6-8.

[4] Pierce, A.F. (1998). Improving the strategies high school students use to conduct research on the Internet by teaching essential skills and providing practical experience. ERIC Document ED427756. Ed.D. Practicum Report. 86p

[5] Bulger, M. (2006). Beyond search: A preliminary skill set for online literacy. The Transliteracies Project. Retrieved December 15, 2006 from http://transliteracies.english.ucsb.edu/post/research-project/research-learinghouse individual/researchpapers/beyond-search-a-preliminary-skill-set- for-online-literacy.

[6] Coiro, J. (2005). Making sense of Online Text. Educational Leadership, 63(2), 30-35.

[7] Kennedy, C. \& Bolitho, R. (1984). English for specific purposes. London: Macmillan.

[8] Burgstahler, S. (1997). Peer support: What role can the Internet play? Information Technology and Disabilites, 4(4). [Online Serial]. Available at http://people.rit.edu/easi/itd.htm

[9] Hutinger, P., Clark, L., \& Johanson, J. (2001). Technology in early childhood: Planning and learning about community environments. Final Report available from Center for Best Practices in Early Childhood, Western Illinois University. Sponsored by Special Education Programs (ED/OSERS), Washington, DC. ED 454680 p 2-75.

[10] Halliday, M. A. K. (1985b). An introduction to functional grammar. London: Edward Arnold.

[11] Schiffrin, D. (1980). Metatalk: Organisational and evaluative brackets in discourse. Social Inquiry: Language and Social Interaction, 50, 199-236.

[12] Hyland, K. (2000). Disciplinary discourses: Social interactions in academic writing. Harlow, UK: Longman.

[13] Crismore, A. \& Farnsworth, R. (1990). Metadiscourse in popular and professional science discourse. In W. Nash, (Ed.), The writing scholar (pp. 119-136). Newbury Park: Sage Publications.

[14] Crismore, A. (1989). Talking with readers: Metadiscourse as rhetorical act. New York: Peter Lang Publishers.

[15] Crismore, A. \& Vande Kopple, W. J. (1997). Hedges and readers: effects on attitudes and learning. In S. Markkanen \& H. Schroeder (Eds.), Hedging and discourse: Approaches to the analysis of a pragmatic phenomenon in academic texts (pp. 83114). Berlin: Walter de Gruyter and Co.

[16] Williams, Joseph (1990). Toward Style and Grace. Chicago: Chicago University Press.

[17] Halliday, M. A. K. (1985a). Spoken and written language. Oxford: Oxford University Press.

[18] Hutchinson, T. \& Waters, A. (1987). English for specific purposes. Cambridge: Cambridge University Press.

[19] Vande Kopple, W.J. (1997, March). Refining and applying views of metadiscourse. Paper presented at the 48th Annual Meeting of the Conference on College Composition and Communication, Phoenix, AZ. (ERIC Document Reproduction Service No. ED411529).

[20] Hyland, Ken (2005). Metadiscourse: Exploring Interaction in Writing. London: Continuum.

[21] Sperber, Dan, and Deidre Wilson (1995). Relevance, Communication and Cognition. $2^{\text {nd }}$. Oxford: Blackwell.

[22] Afflerbach, P. and Cho, B. (2009). Identifying and Describing Constructively Responsive Comprehension Strategies in New Traditional Forms of Reading. Handbook of Research on Reading Comprehension, Routledge, New York and London, pp. 6990.

Ali Zahabi is a $\mathrm{PhD}$ candidate in the field of Applied Linguistics at School of Languages, Literacies and Translation, University Sains Malaysia. He is also a Graduate Assistant at University Sains Malaysia. His areas of research are Reading Proficiency, Taskbased instruction and E-assessment.

Hamed Ghaemi is a PhD candidate in TEFL at University of Tehran, Kish International Campus, Iran. He is a Lecturer at Islamic Azad University. His areas of research interests are E-learning, CALL, MALL, E-assessment, ESP and Teacher Development. He has published several articles in international refereed journals. He is currently the Head of IELTS department at the Jahan Elm Higher Education Institute, Mashhad, Iran.

Ambigapathy Pandian is the Professor and Dean at the School of Languages, Literacies and Translation University Sains Malaysia. He was formerly the Dean of International Graduate Studies and Deputy Dean School of Humanities at the same university. He is a research fellow at the National Higher Education Research Institute (IPPTN). His research interests include literacy studies and higher education. 